\title{
From Roman to medieval Worcester: development and planning in the Anglo-Saxon city
}

\author{
NIGEL BAKER, HAL DALWOOD, RICHARD HOLT, \\ CHARLES MUNDY \& GARY TAYLOR*
}

The modern plan of the west Midlands city of Worcester, like so many in England, hides a series of ancient towns under the standing streets. Archaeological and historical exploration, and the old topography that shows itself in modern plots and street lines, make possible the recovery of the early pattern.

Few if any cities owe their present form to a single period in history: they are composite entities, their present extent achieved by the gradual or rapid addition of new components estates and streets, terraces and individual buildings. While the stages by which a historic city like Worcester has grown over the last two centuries are frequently and easily recognizable, both from the architecture of the buildings and from their layout, reconstruction of how the medieval walled city and its suburbs were established, grew and contracted will inevitably be more obscure. In 1988 the Archaeology Section of Hereford and Worcester County Council began rescue excavations on four adjacent sites in the city centre (FIGURES 1 \& 4). Independently, a joint research project on English Medieval Towns and the Church began in the Schools of Geography and History at the University of Birmingham, funded by the Leverhulme Trust. Its pilot stage was a detailed study of medieval Worcester.

A general plan of the late medieval city and suburbs may be reconstructed from the largescale Ordnance Survey plans of the 1880s, with additional information drawn from 17th- and 18th-century maps, medieval documentation and archaeological research (FIGURE 1). The map shows property boundaries as surveyed by the OS in areas of the city known to have been occupied by the 18 th century or earlier - substantially the medieval built-up area. Archaeological and documentary research in other towns, and in various parts of Worcester itself, suggests that much of this pattern of property boundaries is likely to have originated in the medieval period or earlier, though only detailed research will ultimately reveal the street-by-street balance between survival and replacement (Urry 1967: 150-52, 191; Keene 1985: 180-81; Scrase 1989; Baker et al. forthcoming).

The particular approach to town plans employed by the Project was developed in the 1960 s by the geographer M.R.G. Conzen from earlier German research (Conzen 1968; 1969; Whitehand 1987). Insisting on the fundamental importance of plot-patterns, he analysed historic town plans in detail. Localized internal variations in the character of streets, plots and buildings could be resolved into zones that he termed plan-units (Conzen 1969: 5):

Examination of the town plan shows that the three element complexes of streets, plots and buildings

\footnotetext{
* Nigel Baker, School of Geography, University of Birmingham, PO Box 363, Birmingham B15 2TT, UK. Hal Dalwood \& Gary Taylor, Archaeology Section, Hereford \& Worcester County Council, Tetbury Drive, Warndon, Worcester wR 4 9Ls, UK. Richard Holt, School of History, University of Birmingham, PO Box 363, Birmingham B15 2TT, UK. Charles Mundy, Worcester City Museums Service, Queen Elizabeth House, Trinity Street, Worcester WR1 2PW, UK.
} 


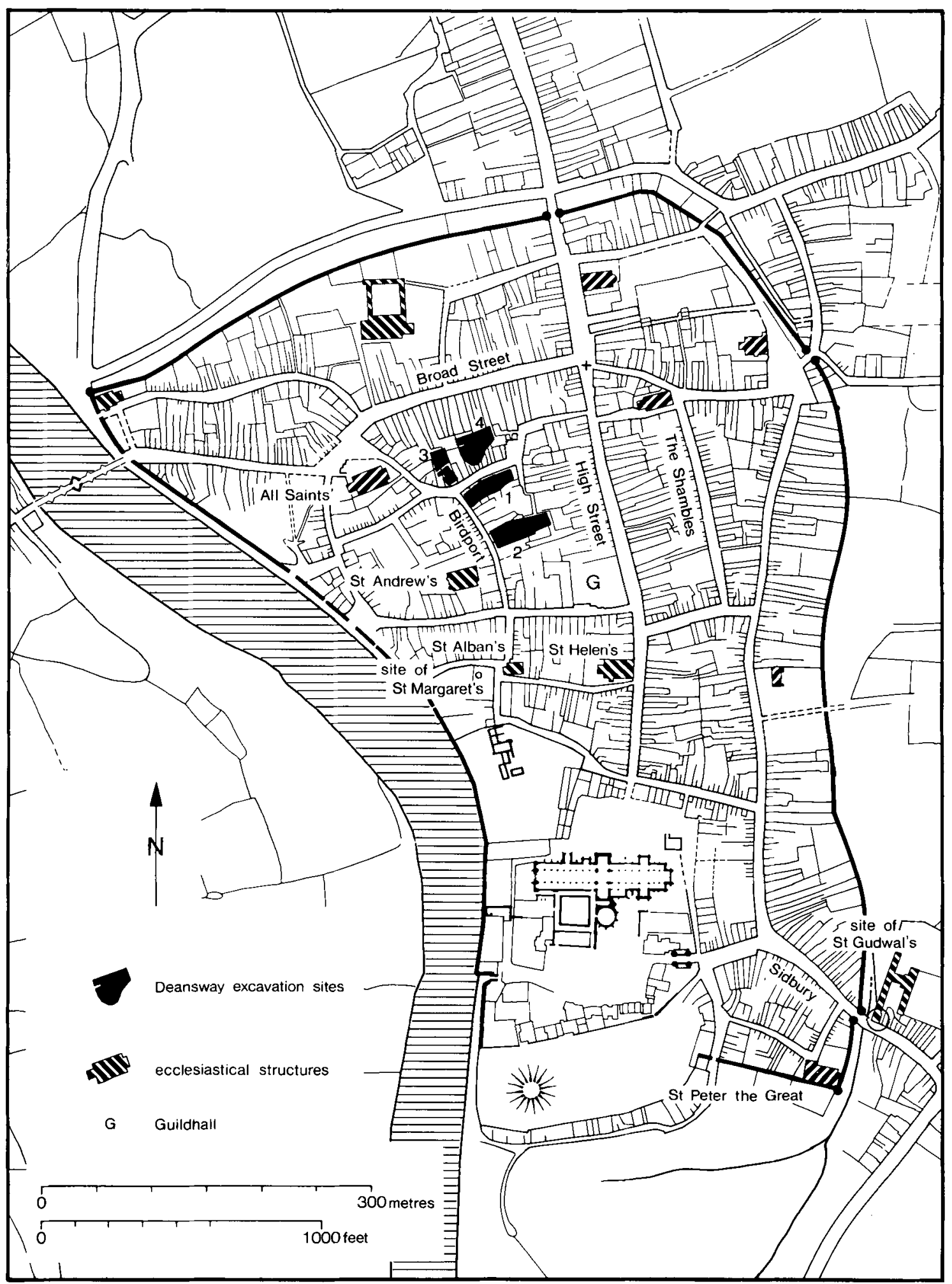

FIGURE 1. Worcester: the medieval intramural city (Baker \& Holt). 
enter into individualised combinations in different areas of the town. Each combination derives uniqueness from its site circumstances and establishes a measure of morphological homogeneity or unity in some or all respects over its area. It represents a plan-unit, distinct from its neighbours.

His analyses suggested that the medieval cores of the vast majority of British historic town plans were likely to be composite in character, with distinct phases of medieval and later growth. Worcester shows precisely this kind of structure.

FIGURE 2 shows the medieval intramural city resolved into its constituent plan-units. Except for the Cathedral Close, these are defined by plots associated with a single street, or with more than one street, where plots or streets have one or more characteristics - orientation, dimensions, shape, siting, function - in common. The variation within Worcester's town plan, and its relation to initial urbanization or re-urbanization, can be demonstrated by briefly comparing the four central plan-units (FIGURE 2:6, 7, 9 \& 10).

Around the northern section of the High Street (plan-unit 6), a rectilinear arrangement of streets suggests a planned origin. Amongst the mass of highly irregular property boundaries, a small number of primary boundaries (Slater 1981), running without deviation from the principal frontage to the street or lane to the rear, define a series of large rectangular primary plots, each with a frontage of c. 156-158 feet (c. $46 \mathrm{~m}$ ). The location of this area, its planned character and its relationship to the known and postulated stretches of the Anglo-Saxon defences suggest it was integral to the late 9th-century burh.

The break-up of another large, early property unit, in this case 'unplanned', may be observed to the west, where the core of the Birdport plan-unit (FIGURE 2:7) had small, squarish, irregular street-blocks, within which individual plots were frequently ill-defined. These blocks represent the sub-division of the private enclosure or haga granted to Æthelred of Mercia by bishop Waerferth in 904 (Sawyer 1968: no. 1280; Birch 1885-99: no. 608), identifiable from its described and measured bounds in relation to the recently-discovered north rampart of the burh (see below and Figures $4 \& 5$ ).

The core of the Copenhagen Street plan-unit
(FIGURE 2:9) to the south consisted of three east-west streets and an east-west northern boundary followed by a post-medieval alley; between these ran fairly straight north-south plots. Allowing for probable northward encroachment by the bishop's palace, the area can be reconstructed as a simple street-grid containing three blocks of equal size. The probable context for this planned development was the reclamation of redundant Roman defences which underlie this area; their massive construction (Barker 1968-9: 50-51; FIGURES 3 \& 5) has left no trace in the visible or mapped landscape, suggesting that they were deliberately removed over a short time. The landscape of the south High Street plan-unit (FIGURE 2:10) was different again: a single street-block equally partitioned between west- and east-facing irregular plots, which again overlay the Roman earthwork defences without reflecting their course. The origins of this plan-unit may therefore also lie in a large-scale organized reclamation, though the subsequent landscape exhibited few of the conventional features of a 'planned' origin.

The interpretation of the plan-units, their date and their significance, frequently depends upon the availability of excavated evidence, as yet available only for a tiny fraction of the medieval walled city. But the implications of the Deansway excavations for the plan-analysis extend beyond the sequence in their immediate area. The discovery of one side of the AngloSaxon defences is of obvious importance; perhaps even more so is the realization of the extent to which the Saxon, medieval and modern townscape evolved from, or was created within, the remains of the Roman townscape. Our relative ignorance of the geography of Roman Worcester therefore sets an ultimate limit on our ability to understand developments in later periods, though aspects of a basic chronology are becoming clear.

\section{The Roman period (FIGURES 3-5)}

The current state of knowledge of the Roman settlement is far from definitive. The Deansway excavations, in the northwestern part of the medieval town, have provided extensive evidence of Roman occupation (FIGURE 4; Mundy \& Dalwood forthcoming) in the area north of the late Roman defences which are of unusual size (Barker 1968-9; Esmonde Cleary 1987: 157). 


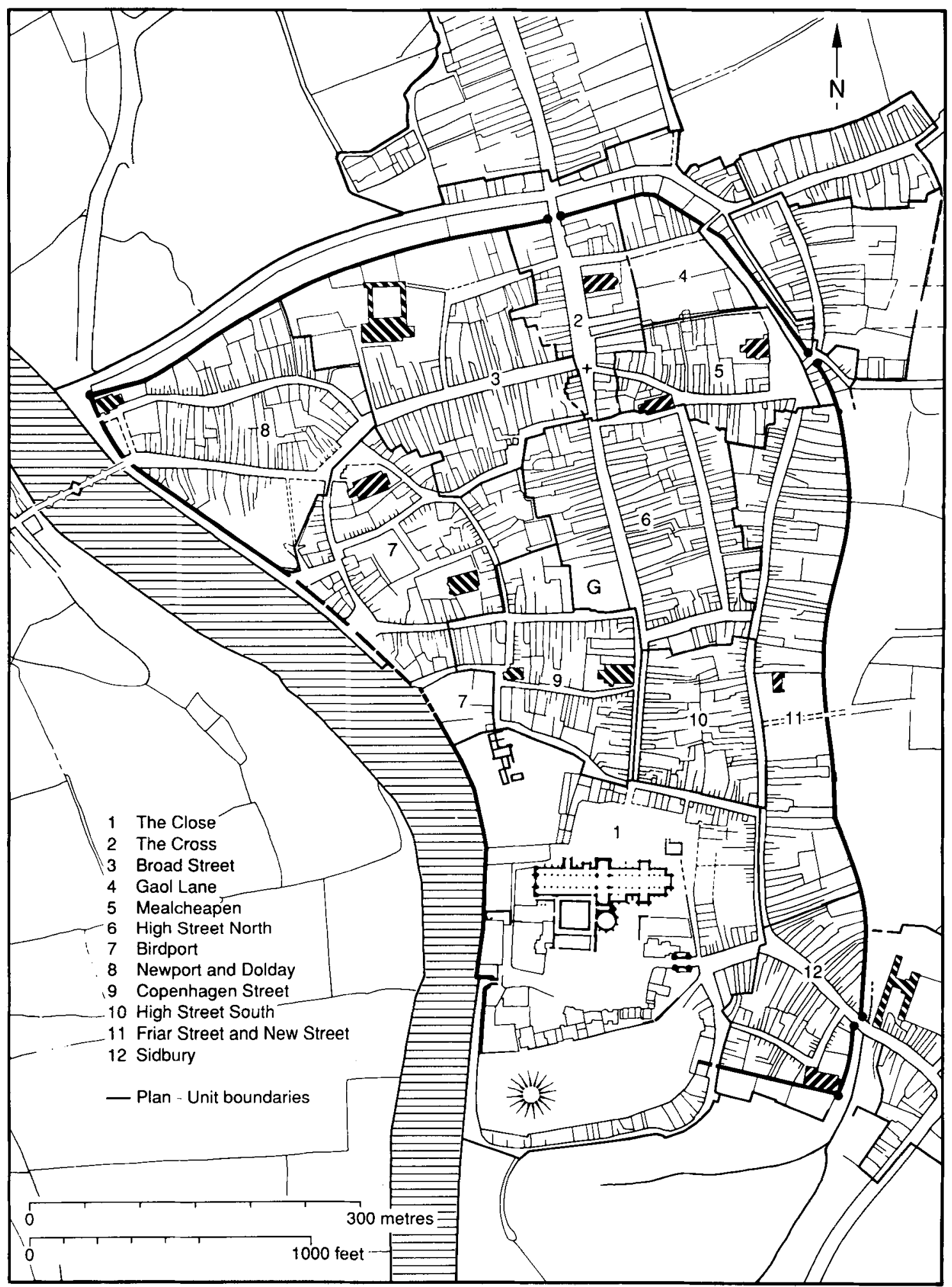

FIGURE 2. Plan-units in the medieval intramural city (Baker \& Holt). 


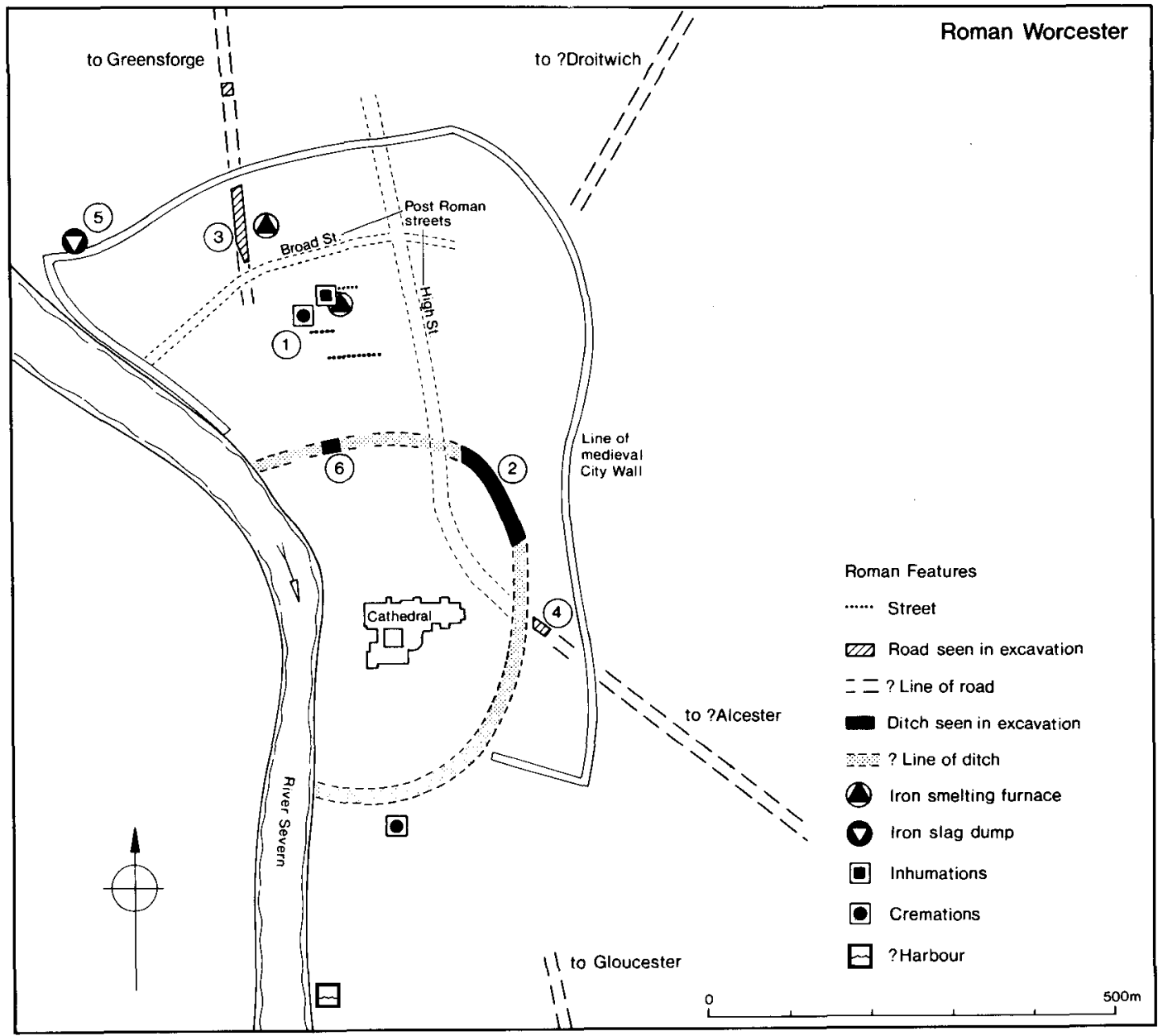

FIGURE 3. Roman Worcester (Hereford \& Worcester County Council Archaeology Section).

While its origin, internal morphology and functional dimensions are still obscure, the settlement can perhaps be assigned to the 'middle order' of Roman small towns as defined by Burnham (1988). As the overwhelming characteristic of the settlement is the evidence for iron-smelting from the 2nd to 4th centuries, Worcester has recently been classified as a specialist industrial site (Burnham \& Wacher 1990: 232-4). Smelting furnaces have been excavated at a number of sites (FIGURE 3, no. 3), and iron slag was everywhere used for road- and street-metalling, as well as being dumped in apparently peripheral areas (FIGURE 3, nos. 3-5).

The recent excavations have also revealed an element of planning in the 'extramural' area: three parallel linear metalled surfaces ran across the excavated areas, spaced c. $35 \mathrm{~m}$ apart (FIGURE 4). While these metalled surfaces and associated features were all overlain by amorphous 'dark earth' deposits, their position and alignments were reflected in later boundaries: the northern street surface by the bank and ditch of the late 9th-century burh defences (see below, and FIGURE 4), the middle surface by Powicke lane (of at least early medieval date and the seam between the Broad Street, Birdport and High Street plan-units), and the southern surface by medieval and later property boundaries. We do not know what ensured the preservation of these boundaries as relict features; the evidence argues against coincidence. 


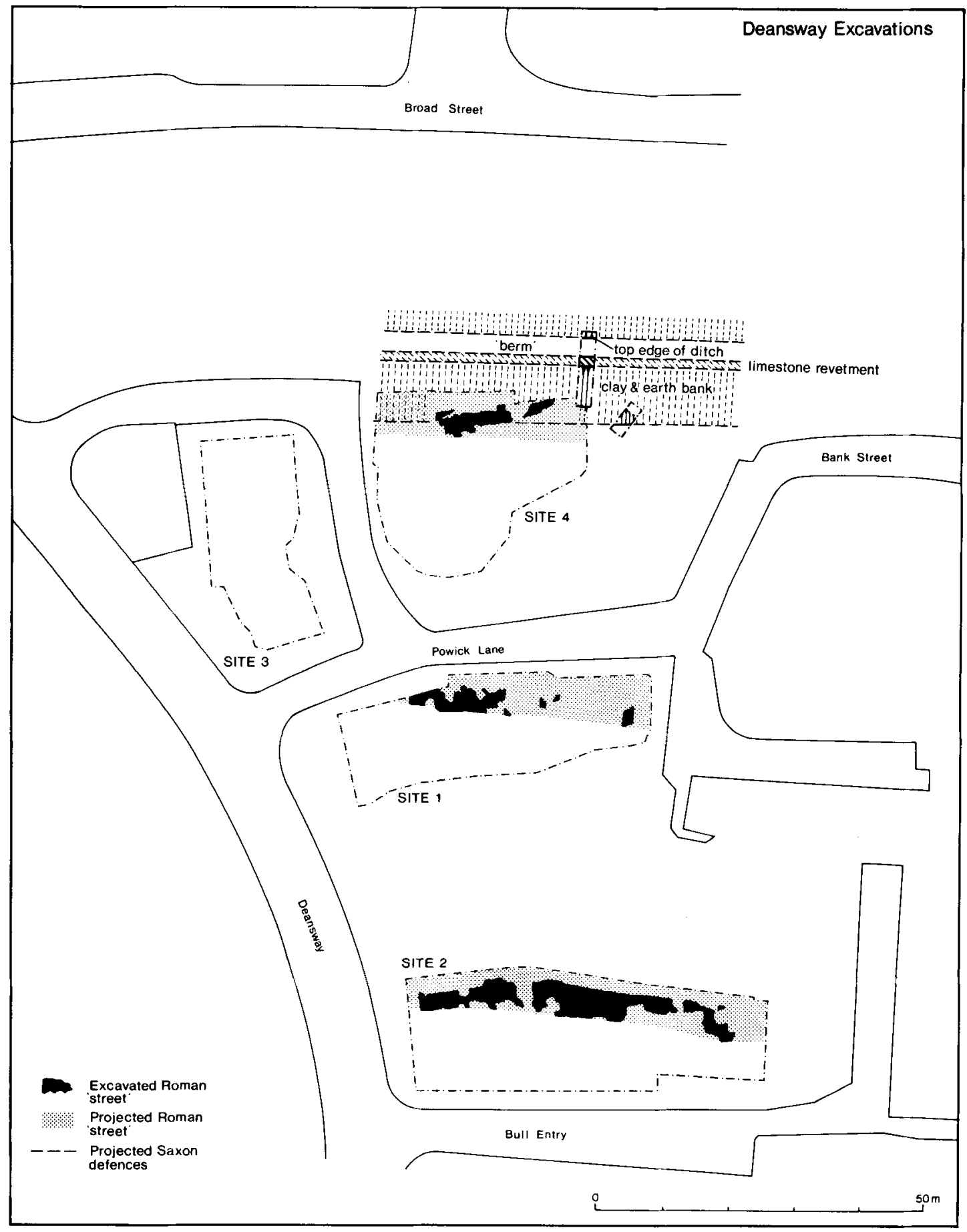

FIGURE 4. The Deansway excavations (Hereford \& Worcester County Council Archaeology Section). 


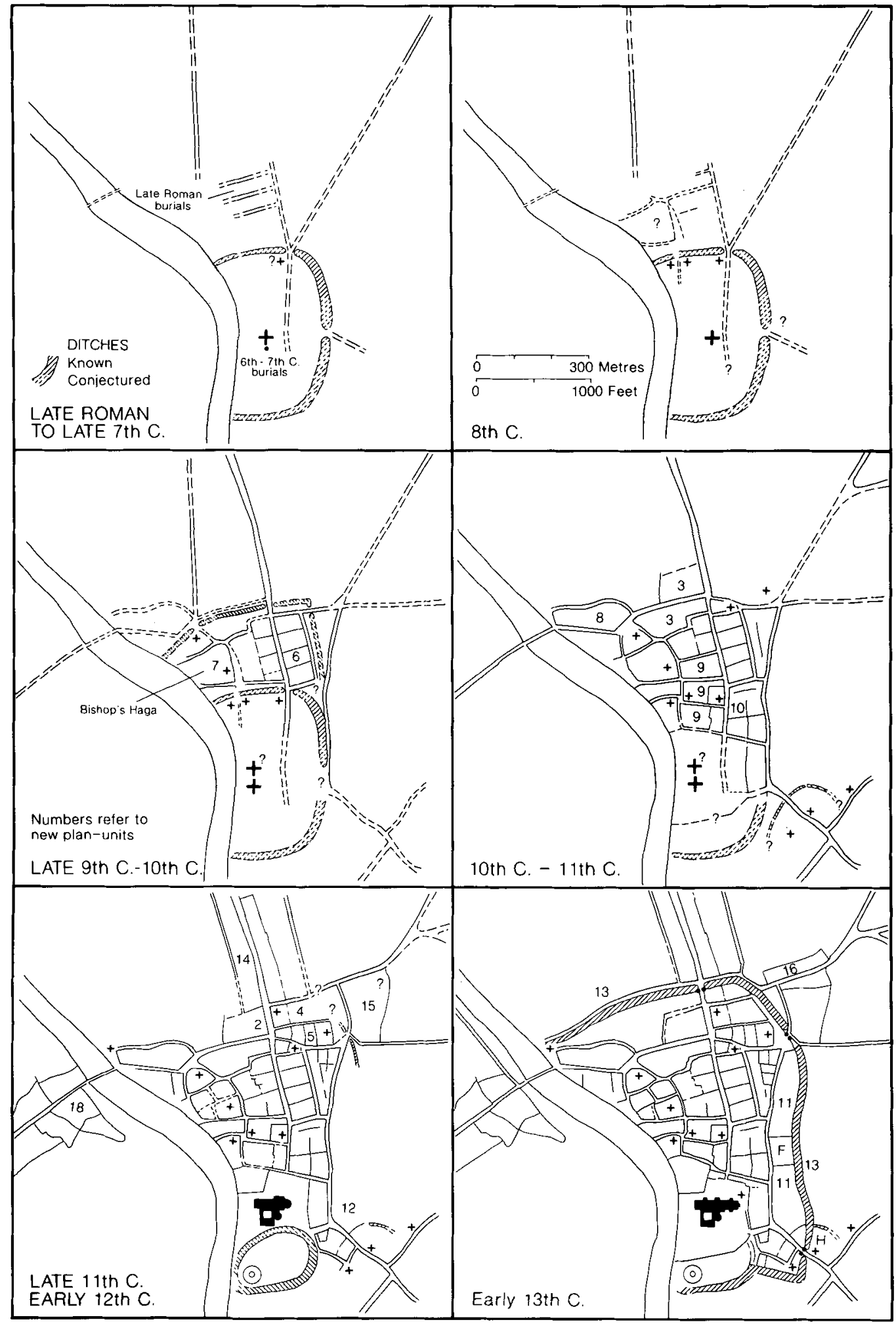

FIGURE 5. Worcester: hypothetical development of the medieval city. 
5th-8th centuries (FIGURES 1 \& 5)

The evidence for the earliest phases of postRoman Worcester is of ecclesiastical institutions occupying the defended area of the Roman town. Historians have long been aware that the massive rural parish that the church of St Helen still possessed in the 11 th century pointed to its earlier importance (Baker 1980: 34); recent work by Dr Steven Bassett (1989) has confirmed its leading rôle in the early Church of the region, and the likelihood that it pre-dated the foundation of the see in 680 . The disposition of other early churches in Worcester is now more certain. Since the chronicle of Evesham Abbey is the only source for Fthelbald of Mercia's grant in 721 to the abbey of the Worcester churches of St Alban and St Margaret, it has been treated with some reservation (Macray 1863: 73; Clarke \& Dyer 1968-9: 27); supporting the authenticity of the reference, however, is the apparent post-Conquest tradition that the antiquity of St Alban's was second only to that of St Helen's (Darlington 1968: no. 52). Its location is consistent with an early foundation: St Alban's was not built in one of those parts of the city that can now be shown to have developed after the laying-out of the burh in the late 9th century.

The newly-discovered position of St Margaret's points to the early origins of this pair of churches. Its previous identification with a 16th-century chapel elsewhere in Worcester is now seen to be incorrect, for it is certain that St Margaret's, too, lay within the northern circuit of the old defences, close to St Alban's church. By the 12th century its dedication had been corrupted to St Marina - confusion between these two near-Eastern saints, long common, was total by this date (Arnold-Forster 1899: $i$, 130; Farmer 1978: 260) and there are several references to the parish of St Marina from the 12th and 13th centuries (Worcester Cathedral Library, Dean and Chapter Records B 1450, B 1451, B 1690; Darlington 1968: no. 340). By 1240 the church had gone, its parish merged with that of St Alban according to the Cathedral Priory register (Dean and Chapter Records A2, 107b, 108; the published edition mistakenly gives the name of this church as 'St Mary': Hale 1865: 107b, 108). After that, 'Marina' was evidently corrupted in popular usage to 'Mary', so St Marina Street became usually St Mary Street (Dean and Chapter Records B 1385, B 1386, B 1028, B 1387). Later evidence identifies this street with Warmstry Slip, the street leading from St Alban's to the river Severn, evidently the location of this Anglo-Saxon church of St Margaret. Perhaps as early as 721, therefore, but in any event before the new burh was constructed in the late 9th century (Whitelock 1979: 99), three churches shared the ancient defended enclosure of Worcester with the cathedral foundation of St Peter's, which itself had existed since at least the 690s (Sawyer 1968: no. 77; Birch 1885-99: no. 75).

From the area to the north of this ecclesiastical enclave there are now some indications of commercial activity pre-dating the foundation of the burh. The origins of the bishop of Worcester's haga recorded in a lease of 904 are unknown, but its riverside location suggests a primarily commercial function like its counterpart in London (Dyson \& Schofield 1984: 296-7). The find of a sceat on the Deansway excavations (Site 2: Metcalf forthcoming) immediately to the east of the 904 haga may show that the riverside here was exploited commercially by the 8th century.

\section{The late 9th century (FIGURES 4 \& 5)}

The southern tail of a rampart, represented by a horizontal clay band, was initially observed in the northern section of Deansway Site 4 (FIGURES 1 \& 4). About $0.1 \mathrm{~m}$ thick, it survived intermittently over a distance of c. $30 \mathrm{~m}$ east to west. Two subsequent investigative trenches showed that the rampart, with clay and earth tip-lines indicating the use of turves in its construction, survived to a height of $c .0 .9 \mathrm{~m}$ and was c. $5.6 \mathrm{~m}$ in width. It had been slighted, and was further truncated by medieval and later pit-digging. The masonry revetment which fronted the earth rampart had also been truncated. Built of limestone and mortar probably robbed from Roman buildings, it was c. $1.2 \mathrm{~m}$ thick at the base and survived to a height of $0.9 \mathrm{~m}$. The revetment may have been supported by timber posts, as a single post-hole $c .0 .25 \mathrm{~m}$ wide was recorded in the wall fabric. Between the front revetment wall and the lip of the ditch, c. $3 \mathrm{~m}$ to the north, was a sand and pebble berm. The total observed width of the defences from ditch lip to the (truncated) rampart tail was $10.6 \mathrm{~m}$.

These post-Roman, pre-medieval defences parallel to Broad Street undoubtedly represent the north rampart of the Anglo-Saxon burh 
established by ealdorman Æthelred and bishop Waerferth during the 880 s or 890 s, though it cannot be demonstrated archaeologically that they were newly built then. The street pattern, and parallel parish and property boundaries, suggest that the east side of the burh lay parallel to the Shambles (FIGURE 1), which probably served as a wall-street. The burh as a whole can now be seen as a defended extension to the surviving late Roman enclosure containing the cathedral. Within, the new burh was divided sharply in two between the planned High Street area and the essentially 'unplanned' area to the west dominated by the riverside 904 haga. This bipartite division was reflected in the (?later) parochial geography, partitioning the area between St Andrew's parish (the church lying within the 904 haga) and the parishes of St Helen and St Swithun. The position of All Saints' church suggests a gate-church associated with an extramural market-place, and with the approach-roads to the river crossing.

\section{The 10th-11th centuries (FIGURE 5)}

Although the dating of these episodes is far from secure, this period seems to have witnessed the levelling for extended settlement both of the northern burh defences and of the north and northeast sectors of the Roman defences. The expansion of the built-up area of the city may also be seen in the appearance of the Sidbury suburb outside the south gate. Sidbury may have been established by the 960 s, when the church of St Peter the Great was already located there (Sawyer 1968, no. 1327; Birch 1885-99: no. 1240). Settlement in this quarter of the city included the probably 10th-century foundation of the church of St Gudwal or Godwald. A hitherto unsuspected Anglo-Saxon church, St Gudwal's is of uncertain status and purpose; it was never to acquire parochial rights. By the early 13th century it had become the hospital of St Wulfstan, but the story of its foundation in the late 11th century by bishop Wulfstan himself (Marsh 1890: 1; VCH Worcs. ii, 175) is clearly incorrect. William of Malmesbury's early 12th-century biography of Wulfstan - a detailed eulogy of virtues and good deeds makes no mention of the hospital (Darlington 1928), and the dedication to St Gudwal points to a different origin. In medieval England, the cult of this relatively obscure Breton saint - celebrated only at Worcester-undoubtedly derived from the monastery of Mont Blandin, Ghent, to which Gudwal's relics were translated in $\mathbf{9 5 9}$ (Bolland 1695: 728-42). The coincidence that it was from exile at Mont Blandin that St Dunstan had been recalled to become bishop of Worcester in 958 is telling: the close contacts that continued to exist between the monks of Ghent and Dunstan's immediate circle (Symons 1975: 45-59) point to this as the most likely period for the origins of the cult at Worcester, and the dedication of the new church.

\section{The late 11th-12th centuries (FIGURE 5)}

The Norman impact on the Anglo-Saxon city is marked first by the construction of the motteand-bailey castle in the 1060 s at the expense of part of the cathedral precincts. The AngloSaxon period had seen the building of two separate but adjacent cathedral churches, in the 7 th century and the 10th, and their replacement after 1084 by Wulfstan's new cathedral may have necessitated the expansion of the close eastward over the High Street. A major new linear suburb - Foregate and the Tything - was laid out northwards along the line of the High Street from the edge of the pre-Conquest builtup area; it was later bisected by the construction of a new defensive circuit.

This model of the physical development of early Worcester, although crude, represents an advance in our understanding of the growth of this particular city - an advance that would not have been possible by archaeological, or documentary, or geographical analyses employed in isolation. Plan-analysis may have a further relevance to the archaeology. In emphasizing the heterogeneity of the townscape and its origins, the plan-analysis also emphasizes the limitations of the existing excavated sample, and the need to extend it - or at least to protect the archaeological resources that would make extension possible. The spatial structure revealed by plan-analysis may indeed have a rôle to play in the management of these resources. At one level, by identifying areas of this (or any other) town that came into existence in very specific circumstances (an act of town planning, for example) it is identifying a physical structure at least as relevant to the history of the fabric of the town as, say, public buildings or defences: it may be appropriate in some cases for plan-units, similarly, to be treated as monu- 
ments and afforded an additional level of protection. At a more general level, historic and contemporary town planning and development have obvious and accessible similarities and

\section{References}

ARNOLD-Forster, F. 1899. Studies in church dedications. London: Skeffington \& Son.

BAKER, N.J. 1980. Churches, parishes and early medieval topography, in M.O.H. Carver (ed.), Medieval Worcester, Transactions of the Worcestershire Archaeological Society 3rd series 7: 31-7.

BAKER, N.J., J.B. LAWSON, R. MAXWELL \& J.T SMITH. In press. Further work on Pride Hill, Shrewsbury, Transactions of the Shropshire Historical and Archaeological Society 69.

BARKER, P.A. (ed.). 1968-9. The origins of Worcester, Transactions of the Worcestershire Archaeological Society 3rd series 2.

BASSETT, S.R. 1989. Churches in Worcester before and after the conversion of the Anglo-Saxons, Antiquaries Journal 69: 225-56.

BIRCH, W. DE G. 1885-99. Cartularium Saxonicum. London: Whiting.

Bolland, J. 1695 [1969]. Acta Sanctorum, Junii I. Antwerp. Brussels: Société des Bollandistes.

BURNHAM, B.C. 1987. The morphology of RomanoBritish 'small towns', Archaeological Journal 144: 156-90.

BuRnHAM, B.C. \& J. WACHER. 1990. The 'small towns' of Roman Britain. London: Batsford.

Clarke, H.B \& C.C. DYER. 1968-9. Anglo-Saxon and early Norman Worcester: the documentary evidence, in Barker 1968-9: 27-33.

Conzen, M.R.G. 1968. The use of town plans in the study of urban history, in H.J. Dyos (ed.), The study of urban history: 113-30. Leicester: Leicester University Press.

1969. Alnwick, Northumberland, a study in townplan analysis. Revised edition. London: Institute of British Geographers. Publication 27.

DARLINGTON, R.R. (ed.) 1928. The Vita Wulfstani of William of Malmesbury. London: Camden. 3rd series 40.

1968. (ed.) The cartulary of Worcester Cathedral contrasts that could provide a link between past and present of fundamental value for promoting the successful management of an urban archaeological resource.

Priory. London: Pipe Roll Society. New series 38.

Dyson, T. \& I. Schofield. 1984. Saxon London, in J. Haslam (ed.), Anglo-Saxon towns in Southern England: 285-313. Chichester: Phillimore.

ESMONDE-ClEARY, S. 1987. Extramural areas of Romano-British small towns. Oxford: British Archaeological Reports. British series 169.

FARMER, D.H. 1978. The Oxford dictionary of saints. Oxford: Oxford University Press.

Hale, W.H. (ed.) 1865. Registrum Prioratus Beatae Mariae Wigorniensis. London: Camden Society 91.

KEENE, D. 1985. Survey of medieval Winchester. Oxford: Clarendon Press.

Macray, W.D. (ed.). 1863. Chronicon Abbatiae de Evesham. London: Rolls. Series 29.

MARSH, F.T. 1890. Annals of the Hospital of St Wulstan. Worcester: E.G. Humphreys.

Mundy, C.F. \& H. Dalwood. Forthcoming. Excavations at Deansway, Worcester, 1988-89.

SAWYER, P.H. 1968. Anglo-Saxon charters: an annotated list and bibliography. London: Royal Historical Society.

SCRASE, A.J. 1989. Development and change in burgage plots: the example of Wells, Journal of Historical Geography 15(4): 349-65.

SLATER, T.R. 1981. The analysis of burgage patterns in medieval towns, Area 13: 211-216.

SYMONS, T. 1975. Regularis Concordia: history and derivation, in D. Parsons (ed.), Tenth century studies: 37-59. London: Phillimore.

URRY, W. 1967. Canterbury under the Angevin Kings. London: University of London. Historical study 19.

VCH. 1924. Victoria County History of Worcestershire 4. London.

Whitehand, J.W.R. 1987. M.R.G. Conzen and the intellectual parentage of urban morphology, Planning History Bulletin 9(2): 35-41.

WHITELOCK, D. (ed.). 1979. English historical documents. 2nd edition. London: Eyre Methuen. 